\title{
Romanian Children in Multiple Worlds
}

\begin{abstract}
The objective of this chapter is to present multilayered situations that children from Romanian transnational families go through, as seen in two dimensions: the first concerns the movement of children between countries in relation to the educational system, and the second contains elements of identity and children's allegiance to countries they (also) live in.
\end{abstract}

Keywords Children $\bullet$ Education $\bullet$ Hybrid identity $\bullet$ Belonging

\section{INTRODUCTION}

After the fall of communism, the number of adults living for a longer or a shorter time abroad started to increase. These adults were joined by children who had either left Romania with their parents, joined them after some time, or were born abroad. The movement of adults is not onedirectional, since the stories presented in this chapter generally concern people who either are or were at some point in a state of transnationally suspended living (see Chap. 5), that is, they do not have/have not had the slightest intention to be definitively integrated into the target country. They move to and fro between the countries of origin and destination, and the children are caught in between these movements. A growing number of Romanians also changes their target countries (see Chap. 4)-and they have children too; their situation, however, is not addressed in this chapter. The way in which education is provided in the diverse situations that

(C) The Author(s) 2018

V. Ducu, Romanian Transnational Families, https://doi.org/10.1007/978-3-319-90242-5_5 
these children go through, as well as the aspects of their cultural identities and allegiances to certain countries, will be presented here through the voices of 11 women and 2 men. The testimonies have been gathered in various countries (Romania, Belgium, the UK, the USA, Canada and Egypt), and, most importantly, they come both from families where both partners are Romanian and from ones where the parents are a mixed couple. This comparison is critical, since it reveals the less-visible aspects compared to what one would find from a single perspective. The objective of this chapter is to present the multilayered situations that children from Romanian transnational families go through.

In the first part, we will offer a short review of the theoretical framework relevant to this chapter. The presentation of the research results will follow, in two dimensions: the first concerns the movement of children between countries in relation to the educational system, and the second contains elements of identity and children's allegiance to countries they (also) live in. Finally, we shall offer some concluding remarks.

\section{Theoretical Framework}

In the last few years, we have noticed an ever-increasing research interest in children involved in transnational families. Indeed, we have observed that three edited volumes (Spyrou and Christou 2014; Nagasaka and Fresnoza-Flot 2015; Seeberg and Gozdziak 2016) and special issues of journals (White et al. 2011; Mazzucato and Schans 2011; Gardner 2012; Carling et al. 2012) have been dedicated to this topic.

Regarding children from Romanian transnational families, very few studies have focused on this segment compared to the impact of the phenomenon.

The situation of children who are left behind is mostly addressed in studies that explore various topics, including the emotional impact of separation from one's parents, the effects of parents' absence upon the education of these children (Robila 2011; Bezzi 2013; Botezat and Pfeiffer 2014; Sănduleasa and Matei 2015; Popa 2016) and the retrospective stance of youth raised in such circumstances in relation to their experience of a childhood with their parents abroad (Rentea and Rotărescu 2016).

There are very few studies on Romanian children involved in migration within the EU, or "Intra-European family migration" (Moskal and Tyrrell 2016; we should also mention the volume edited by Valtolina in 2013), especially those that address their relationship to the target country (e.g., 
Italy-Valtolina et al. 2013; Spain-Trias et al. 2013) or the country of origin (Bratu 2015). Children in Romanian transnational families from the extra-European space are even less present within research.

"The open-ended orientation of many of the families allows diverse future scenarios" (Moskal and Tyrrell 2016, p. 464) and "certain types of childhood fit into, are shaped by, and shape certain types of society while other types of childhood go with other types of society" (Seeberg and Gozdziak 2016, p. 3). "Migration places children in new social and relational contexts, different in terms of family and friends they can rely on in their everyday lives" (Sime and Fox 2014, p. 15). For these children on the move, one important issue is switching between the educational systems of different countries.

"Mobility has also been described as some sort of mental process rather than a physical process" (Wentzell Winther 2015, p. 215). One example of this concerns the dreams of migration among children from Ghana (Coe 2012), who, although they have never left their country, are already in this state of physical mobility through these future projections. The future of children in the context of migration can often be associated with their projection, not only of departure, but also of returning; hence, they have a sense of belonging to their country, which is affective, rather than administrative. In the case of Romanian youth born in Romania and raised abroad (the " 1.5 generation"), the "typology of ways of relating to [the] home country [is] divided into strong, ambivalent and low attachment to the home country" (Bratu 2015, p. 22).

Closely tied to the feeling of belonging is the identity of these children who are in between countries; this is strongly mediated through language, style of dressing and even skin color (Rysst 2016). These children develop a "hybrid identity drawn from everyday cultural practices and a combination of the host country and home country culture" (Vathi 2015, p. 63).

This chapter is written from the perspective of adults, with the children treated as its objects, not subjects. Transnational parenthood tends to be seen only from the perspective of departed parents and their relationships with children at home. However, all migrant parents joined by children who intend to live for a limited amount of time in a country "do" (Morgan $201 \mathrm{la}, \mathrm{b})$ something similar to transnational parenthood, since the entire set of practices - from birth, if this is the case, to child raising and educationare submerged under a transnational setting between the country they are in and the one they will be in: from prospective citizenship, language or decisions concerning the education system. "Transnational parenthood is 
affected in gender-specific ways" (Carling et al. 2012, p. 193). Mothers are considered to be prominently responsibly for transnational parenthood, but the introduction of the perspective of fathers has been rising (Mazzucato and Schans 2011). In Romanian transnational families, "mothers are the ones considered the main provider of emotional closeness" (Robila 2011, p. 331), while the fathers apparently become less involved or are sometimes only a pretext. In order to fulfill their return wishes, as Vlase (2013) illustrates, fathers may use children's education as an argument for the family's return: "the real reason for return is the husband's preference, while the children often serve as justification" (Vlase 2013, p. 754). Even in the case of Romanian parents who are raising their children in Italy, "some Romanian interviewees reported having egalitarian ideals, despite asymmetrical practices" (Santero and Naldini 2017, p. 10), with mothers remaining responsible for raising the children. "Romanian fathers appeared more likely to rationalize the gap between egalitarian ideals and asymmetrical practices in terms of different (biological) predispositions" (Santero and Naldini 2017, p. 10) between men and women. Indeed, the present chapter confirms the interest of women within the family as being of child raising and education, women being the primary respondents with such concerns within our research. Fathers become visible in more special situations, such as in binational couples, who share their experience about delicate decisions concerning citizenship, language and religion, along with a heavy concern for developing the Romanian dimension of the children's hybrid identity.

\section{Children Moving 'To and Fro’ and the Relationship With Educational Systems}

\section{A Better Western System}

"Although there [...] [are] a significant number of children left in Romania, some families - especially if they are intact - migrate together with their children" (Bradatan 2014, p. 374), or the departure of the parents is often followed by the departure of the children. The fact that children need to be with their parents is self-evident and somehow more pronounced in the case of Romanian transnational families, who-especially the mothers-have had to confront a heavy wave of accusations of abandonment (Ducu 2013, 2014). Therefore, the family, including the extended family (grandparents, for example), views the departure of children as natural, although extremely painful. 
Often the relocation of the child is well received by the family, since, by migrating to the West, the children have access to a more modern education system compared to the Romanian one. Stela told us, with enthusiasm, how her granddaughter managed to become integrated relatively quickly into the UK.

Here she didn't get enrolled, here she needed to get into the zero grade, and there, since they start school at five, just like that [...] they enrolled her directly into the first grade. [...] And now she is in the third. It was not easy, but she adapted very quickly. School there is a little different from here, it is much closer to the pupil. It's like this: [...] after they have the lunch break, for example, after they have the lunch break and the play break, since they play in the yard and eat there, after that there is an assistant teacher, one who manages four children, so it is a kind of after-study there. They are not given any homework. (Stela, Romania)

However, there are situations in which only the children migrate in order to go to school abroad. Marilena told us how, since she had an adult child in France as well as several members of the extended family, she decided to send her 14-year-old to study there in order to give the child the opportunity to access an education system that was superior to the Romanian one. Even if this was a success story (since the child grew into an adult who went onto take up a leading position and became part of a mixed couple with a French woman), Marilena can never forget the sacrifice she made by being separated from her child so early on.

Very painful! So, when I left him there it was very awful! So, I couldn't stop crying and I cried until Paris. I had the urge to tell the man: mister, stop, let me get back to take my child! (Marilena, Romania)

This attitude of idealizing the Western educational system aims to emphasize the idea that the departure of children is not just about accompanying their parents; it is also about better educational opportunities. The story of Marilena is an example from the past, where cases like hers-sending the children without the parents-were rare. A growing number of Romanian parents take such decisions on their children's part and make a special effort, especially for the period of high school, with the aim of ensuring access to prestigious foreign universities. Johana, a financial manager in one of the large Romanian private companies from her town, was trying to sell a fairly important property for her family in order to support her son, 
who was studying at a high school in the UK with the goal that he would later go onto Cambridge University. During his free days, the teenager was working part-time in the UK in order to be able to support himself.

Since these decisions often imply large financial efforts, people try to access a scholarship system. Adriana, the vice manager of a well-rated high school in a small town in Romania, besides being the leader of a group of professors who voluntarily worked with the children in order to prepare them for applications to foreign universities, has struggled to set up a program at her institution, which would allow high school students-including her son-to study in Germany in their final two years, thus guaranteeing them higher chances of going to a foreign university afterwards.

These children who leave Romania and study abroad by themselves are completely missing from current research, as well as the children who give up finishing school here and leave for work abroad without their parents. Some of them manage to enroll in the education system abroad in order to continue their studies.

\title{
RETURNING TO ROMANIA
}

Situations where parents who have migrated together with their children decide to return home are frequent, but the parents' decision is not shared $100 \%$ by the children, especially since they have difficulties in using the Romanian language. Flavia told us with emotion of her son's attempt to adapt, after which he returned to Italy.

\begin{abstract}
He did the first grade there. In the beginning, he liked it, but he didn't want to. [...] And it was very difficult for him at school. [...] He was afraid since he didn't manage to speak well. And now, he still has a little difficulty in articulating words, but he speaks very well! I didn't expect it so quickly, since he has been [in Romania] four months. [...] And he made his group of friends, he is an open type, he isn't one to get ashamed. He goes, he doesn't know, he goes and asks, he plays. (Flavia, Romania)
\end{abstract}

Flavia has come back from Italy with her son and with her daughter, who is a few months old, earlier than planned, precisely in order that the boy can start school in Romania, since he had already started school in Italy, and she did not want him to be integrated there too much and have difficulties in Romania later on. Her husband stayed in Italy for an undetermined period, hoping to eventually join the family as well. 
The destination countries are not always Western, and the course of political events sometimes changes the opportunities that parents have abroad, from better opportunities for the children's education to very unpleasant alternatives, whereby the educational system that the children have access to becomes a reason for returning to the country. Cristina was just preparing to return to Romania with her children in order to have access to a better-quality teaching system. Living in Egypt, after the Arab Spring, her situation, along with that of her Egyptian husband changed and are increasingly worse off financially. Whereas before they could afford to send their children to the most expensive, elite schools in Egypt, now they are facing the threat of having to use the ordinary public system, which is very poor compared to its equivalent in Romania. In order to save the children, who also have Romanian citizenships, from this situation, Cristina has decided to return with the children, while her husband remains in Egypt for the time being.

Yes, obliged - forced! Because now, [...] for about six years since the Egyptian revolution began, have just about lost our businesses. Inflation is very high, and the schools became [...] So, they have three kinds of schools. There is the state school, [...] in fact, you cannot call it a "school", it is a ghetto, nothing more. [...] These are the state schools. There is an "experimental" school, which is what they call it, where the school is better equipped. It costs a little more than the state schools, approximately [...] let's put it in lei, 2,000 lei, you know? [...] Where, at least the children are more quiet, a little more protected. At least they have a toilet they can use, the poor ones. But, at the level of teachers, it is very much wanting! There is a fourth option, too, a third one, sorry, that is a private school, but it goes together with the national curriculum, where we pay something like 20,000 lei. So, you see how much it jumps, from 2000 to 20,000 lei [...] And we also have the last option, which would also be the most ideal one and the one that we tried and, in fact, that's how we started school here, in Egypt - it is the International American School, where we pay 50,000 pounds a year [...] We couldn't sustain this anymore, because our legs were cut off, you know? The businesses have been lost too, they've been lost and we haven't had a workplace either [...] they cut it all for us, suddenly! I was forced to take the kids out of the American School when they were already in the fourth grade. So, being used to a more relaxed, better system [...] Right. Er, now, during the last three years, we haven't managed to pay this school of 20 [thousand] [...] We have come down to $[\ldots]$ they do some things here like $[\ldots]$ they call it a game. Where everybody puts money and each takes for the month in question, all the money, to pay for their schools. So, we are returning out of necessity. We said that 
I would rather go and take my slaps on the head in Romania, but at least I am not paying anymore, yo, bro! And I can feed you like humans! (Cristina, Egypt)

As we can see, transnational parents must be ready up to a point for a possible return of their children and prepare them for integration into the Romanian school system. The most difficult problem in these situations is not knowing the Romanian language well enough for the integration to take place easily (as in Flavia's case).

It is not just the children, however, who change educational system, because of their parents' decision to change countries, but sometimes it is the parents who need to change countries in order for the children to have the opportunity to access a better educational system.

Cristina, who is part of a mixed couple, has missed this preparation, especially since she did not view herself as a transnational parent and had not taken into account the possible situation of a transnational life for herself and her children. She saw herself as always living in Egypt with her husband. Since it became impossible for the children to continue their studies in Egypt, the solution that the family adopted was to send the children with their mother to live in Romania until they complete high school, with the mother returning to Egypt afterward, while leaving the children to decide whether to go onto a university in Romania or in another country. Happily for them, even if they had not taught their children Romanian, there are numerous international schools in larger cities in Romania with English as a teaching language and of a better quality than what she could access in Egypt. Thus, at the time of meeting her, Cristina and her children were about to move to a larger city for the sake of the children's schooling, although not in the same part of Romania where Cristina was born and where her family was living.

We have also encountered the strategy of sending the mother back to the country earlier than would otherwise be necessary, in close connection with the educational system in the case of Júlia and Tibi, the ethnic Hungarian couple from Romania who were living with their two children in the UK. Given that their son was facing difficulties in meeting expectations during the first school years in the UK, while their daughter was about to start school as well, the couple decided that Júlia should return with the children to Romania earlier than they would have wanted and to enroll them into the state educational system. The children joined an alternative teaching method group—called "step by step"-which is 
something similar to how their son was taught in the UK, in order for him to adapt more easily. Tibi joined them after a few years.

We have similarly witnessed the decision to choose to live in Romania, for at least the children's compulsory schooling duration, in the case of an American woman, Shannon, and Levi, an ethnic Hungarian from Romania, who had lived in various countries, one after another. When their child approached the age of four and needed to go to school, they did not choose the USA for the child's education, as they were completely dissatisfied with the quality of the state education system that they could afford there; they decided to select a village in Romania, where they also bought a house.

These complex combinations between educational systems that transnational family members have access to show us the difficulty of deciding, especially when speaking of the education of one's children, which country one prefers to live in. We have, for that matter, encountered a significant number of families - especially in Spain and Italy - who have failed in their attempt to teach their children the Romanian language above the conversational level, that is, reading and writing, and have also postponed returning to the country for the first school years, when they had little to catch up with, although they would have liked to, until finally this became impossible for them, due to the integration of the children into the educational system.

From the experience of these families, we understand that belonging to one educational system or another can play a major role in the constellation of the family and the localization of its members over time. These families "are done" (Morgan 201 la, b) and "redone" depending on the decisions taken at certain times concerning children's education. While adults are relatively "free" to choose their workplace and country if they so wish, for children who are enrolled in an educational system (something compulsory in many countries), gliding is not all that simple; hence, temporary suspended transnational living (see Chap. 5) is, for many families, prolonged for the duration of the children's schooling period, or at least one cycle thereof. International schools abroad or in Romania are available for some of these children who glide between multiple educational systems, but not for all. 


\section{Elements of Identity and Allegiances AmONG CHILDREN}

Speaking the Romanian language, as well as keeping the Orthodox faith, is decisive for the development of the Romanian component of children's hybrid identity (Vathi 2015; Rysst 2016) in families that find themselves in a state of temporary transnational suspension. Children born abroad are given the opportunity to obtain citizenship of the host country in the future; but in more difficult situations, such as multiple possible citizenships, parents need to make choices. Beyond mere administrative allegiance, parents also confront the emotional belonging of children to one country or another, feelings that are not necessarily in accordance with future plans if parents who-in these temporarily suspended situations, at least theoretically-mostly want to return to Romania.

\section{Speaking the Romanian Language}

The classical strategy of communication mentioned by families with children living for various periods abroad is this: they speak Romanian at home, and they speak the language of the target country at school. Our respondents mentioned, with pride, that their families manage to communicate with their children in Romanian, while the level of success was even higher if the children had been born abroad. The parents, especially mothers, often make an effort to keep the language alive, beyond the conversational level. They appeal to various online acquisitions of children's books in Romanian or to various exercise materials and try to practice reading and writing the language at home. Many Romanians follow Romanian-language television channels in their homes when abroad, while the fact that many foreign-language television shows or films are still not dubbed-but subtitled-forces the older children to practice reading in Romanian as well. The effort to retain the language is maintained, especially given that the language of the host country is usually the "playing language" of children outside their home, as well as frequently inside it, among siblings. Since they socialize in playgrounds and at school using the host country's language, it seems natural to the children to continue playing in the same language among themselves, even if their parents speak another language.

The most illustrative role of language is highlighted in the case of children whose parents form a mixed couple. The way in which binational 
couples use language to communicate within the couple and with their children is a key part of the configuration of mixed families' functioning (Ducu and Hossu 2016). Beyond the usual situation in which either the minority partner is completely assimilated and the child does not learn the minority language or the majority partner's language is spoken in the household, while the child also learns the language of the minority partner, lately one can encounter mixed couples in which the partners do not speak each other's language at all, but speak to each other in a third language.

We present below the language practices that two binational couples living in the UK-Cristi and Petra (Romania and Czech Republic, respectively), and Adi and Katarina (Romania and Latvia, respectively)-have developed in order to maintain the hybrid identity of their children and the ethnic component brought to the family by each partner.

$\begin{array}{ll}\text { Katarina }(K): & \text { When I'm alone, I talk to her in Latvian. When we are } \\ & \text { together, we speak English and... } \\ \text { Adi }(A): & \text { I am going to speak Romanian to her. } \\ K: & \text { So, the main language for her, we want it to be English, but } \\ & \text { still, we are going to teach her Latvian and Romanian as well. } \\ \text { A: } & \text { It is going to be good, you know, at least the basics to know in } \\ & \text { Latvian and Romanian. }\end{array}$

I'll speak Romanian to her, but in different situations. Our plan is like this: I'll speak Romanian to her only when I am alone with her. She [his wife] will speak Czech to her only when she's alone with her and we'll speak English when we are together, cause the trick to it is not to teach her the actual languages, cause that's easy enough, but the trick is to get her to talk to you in the language you are requesting. (Cristi)

These efforts made by parents, especially in mixed couples, to keep the Romanian language alive are strongly associated with temporary transnational living. It seems that when the relationship with Romania starts to fade, the idea of ever returning and living there disappears (either due to parents' renouncing these plans or due to family decisions, for example that of grandparents' moving abroad, which completely disaffected the relationship with Romania) and the efforts of parents to keep the language alive dies; all this is usually associated with children's "refusal" to speak Romanian. The case of the couple formed by Mihaela and Andi is illustrative here. Andi was born in Romania to a Romanian mother and an ethnic 
German father, having Romanian citizenship. During communism, under the large repatriation program of ethnic Germans, the father wished to emigrate to Germany, but the mother refused; so they divorced and Andi remained with his mother in Romania. After the revolution, Andi, now an adolescent, wanted to move in with his father in Germany. He maintained contact with his circle of friends in the country, and, during his vacations spent in Romania in his student years, he met Mihaela. After a transnational relationship lasting two years, and already pregnant with Maia, Mihaela moved in with him in Germany, and they were married. She spent much time and energy with Maia, so that she could learn Romanian and have a relationship with the country. They continued communicating with relatives and friends transnationally, and spent all their holidays in Romania. When Maia turned ten, Vlad, her little brother appeared. This was the moment when Mihaela decided that her mother, her only relative alive in the country (her sister had meanwhile moved to Italy together with her family), should join her in Germany. This was the moment when her relations with Romania "cooled off." We also witness a change in educational practices at this precise moment: it would have been logical that once the grandmother has joined the family as well—even if not living in the same house, but in the neighborhood, not having any other acquaintances but them-and when they also had a new family member (Vlad), they should continue speaking Romanian with more enthusiasm. It was the exact opposite that happened: under the pretext that Maia refused to speak Romanian in line with her friends, Mihaela and Andi decided to only speak German to their children. Hence, they reached the paradoxical outcome whereby Vlad, who is now seven, has never learned Romanian, meaning that the grandmother cannot communicate with her grandchildren at all, although they live very close by and visit each other daily.

A similar situation can be found in Zsuzsanna's case, a Romanian citizen of Hungarian ethnicity living in the USA, who is married to Ben, an American citizen. Zsuzsanna invested much energy during the first years of their daughter Kira's life to teach her Hungarian, the language of her relatives in Romania, and was making serious plans to teach Kira and Ben Romanian as well. The first years of the girl's life coincided with the time when they built a villa in one of Romania's large cities (her native city), while they lived in a tourist village in the USA. Building the house was associated with the possibility that the family might, one day, move to Romania and have a life here. However, financial crisis kicked in and the family was unable to bear the burden of all the loans for the two houses 
(the other being in the USA), so they put the house in Romania up for sale. Meanwhile, her mother died and the family's plans changed. Instead of making further plans for a life in Romania, they decided to start planning to bring over the living grandfather to the USA, even though he spoke no English. Associated with these events and with the change in life plans, they decided that Kira should not speak Hungarian anymore, since there was a slight accent that people sensed at school, and Spanish was enough for her as a foreign language.

It is interesting to note that, in these two situations where mothers insist on the linguistic component while projecting their family in a transnational situation with Romania, as their orientation toward a future is oriented toward the host country, they come to the conclusion that it is in the interest of their children to learn the language of the latter as well as possible. This is even if-as we have seen in both situations-the grandparents cannot communicate with the grandchildren at all anymore, given that they do not speak the language of the country they are being moved to, thus becoming completely dependent on the adults and somehow isolated even within the family.

\section{The Choice of Religion/Rite}

It is noteworthy that children's baptism is very important to Romanian Orthodox couples who have children abroad. This practice reinforces a child's claim to a Romanian identity, as the Orthodox rite is strongly associated with Romanianness. Besides, the Romanian Orthodox church is strongly present within Romanian communities abroad. Romanians go to church services as a practice in which their identity as well as their belonging to this community is manifested, even if they need to go to another town to do so-for example, our research respondents in Mons had to go to Brussels on Sundays in order to attend liturgy.

If it is generally easy for Romanians to adhere to the Orthodox rite, similar to Albanian Muslims who are able to keep their allegiance to Islam in the UK (Vathi 2015), in the case of children born in binational or ethnically mixed couples, we have encountered a certain discomfort, similar to that of Albanian Muslims in Greece and Italy (Vathi 2015), among family members when needing to choose. It seems that the extended families in Romania manage to impose their wish for these children to be baptized as Orthodox, rather than the other partner's religion (Ducu and Hossu 2016). 
Adi and Katarina chose to baptize their daughter in the Orthodox rite, even if they are not married, under pressure from Adi's parents.

I am Orthodox, she [his wife] is Lutheran. [Q:And R. - Their daughter?] She is Orthodox. Anyway, we're not into that religious stuff, but... you know, I had some arguments with people, like, 'You said you're not religious, but why did you baptize your kid?' Or, 'Why do you, when you're not married, go to the church?' Because I have parents and they are like, 'Tititititiiti, do it! Do it!' You know, it's annoying, but you have to listen to them sometimes. (Adi, UK)

We encounter a similar situation in the case of Luiza (Orthodox) and Andrew (Methodist), who were yet undecided with respect to the baptism of their daughter, but were persuaded by Luiza's mother to arrange for the baptism in the Orthodox rite.

Mum, since she came here, has kept reminding us to baptize the little girl! Yes. And finally, we recently decided to baptize her in the Orthodox community and then she can do what she wants later. (Luiza, USA)

The impact that the larger family has upon choosing a religion in the case of binational children is highlighted by the story of Virginia's child, who was baptized by the grandmother without agreement from the parents:

The boy is Orthodox, we baptized him after three years. At the beginning, it was very hard, but, after three years, we said let's baptize him, and we did. I mean, I don't want to lie, my mother baptized him when we sent him on vacation [...] Aurica did it without permission, and my sister was the godmother. And he was three years old. Since then he's very religious, he loves the Bible. At Easter and Christmas, he goes to Church, he knows "Our Heavenly Father" in both Romanian and English, he knows both Bibles but... no, he's Orthodox! (Virginia, UK)

The set of practices (Morgan 201la, b) through which the family manifests its belonging to the Orthodox rite-respecting the traditions pertaining to the Orthodox religion, attending religious services, the baptism of children-is another way for them to perform displaying family (Finch 2007, 2011; Dermott and Seymour 2011) qua a Romanian Orthodox family (Ducu and Hossu 2016) and to reinforce the Romanianness of their children. 


\section{Children with Multiple Potential Citizenships}

As an effect of the massive migration of young adults from Romania, ever more children belonging to couples, which include a Romanian partner, are born abroad. Often, this means they have the opportunity to access at least two citizenships in the future: Romanian and that of the country they were born in.

This is the case for Ana's child, who was granted Romanian citizenship as well, despite being born in Canada.

He is a Canadian and a Romanian citizen. [...] Yes, we got him a Romanian passport and a birth certificate and everything. (Ana, Canada)

The children of mixed marriages often have access to dual citizenship. This is the case for Ema, who was born in the USA to a Romanian mother and an American father. Luiza wants Ema to obtain Romanian citizenship in the future as well, since she has a "natural right" to be a citizen of the state her mother was born and raised in, and where members of her extended family are living.

Well, look, it is in a way simple. For example, since she was born here, she is automatically an American citizen. So, there is no strict probibition against dual citizenship. [...] She has this natural right, so to say, and she can invoke it anytime. But she must fulfil certain demands. In Ema's case, [she needs] to show her birth certificate and to show that I am a Romanian citizen. (Luiza, USA)

Ever more binational couples live for certain periods of time in a third country, different from any of the countries of origin of the partners (Ducu and Hossu 2016), while an ever-growing number of children are born to such couples. In their situation, the parents need to decide, on the child's behalf, which citizenship (or more) to access. This is the case for Petronela, who was born in the UK, whose father Cristi is a Romanian and whose mother Petra is a Czech.

Cristi: Yes, she was born in the UK. She doesn't have a UK passport and she can't get one until she's 18. She is a resident of the UK, she has a UK birth certificate and, if we wanted British citizenship for her, first of all, one of us has to earn it. So, we can't get it [for her] until one at least has it and you 
bave to be in this country for longer than five years, I believe... I am not going to bother with that. I am not very interested in British citizenship, not for me, not for her, not for my daughter.

Question: Is she Romanian then?

Cristi: She is nothing yet!... We applied for Czech citizenship, just because it lasts a few weeks shorter compared to the Romanian paperwork. This was the only choice. We are waiting for the papers. [...] Until she gets her passport, we can't go anywhere with her. I mean, we can, but we can't come back until everything is sorted. [...] We are going to apply for Romanian citizenship as well. Both of these countries allow dual citizenship, so why not?

Similar to children born abroad being eligible for Romanian citizenship, even if they grow up abroad, an increasing number of children born abroad-even if they eventually move to Romania-have the right to request the citizenship of the country they were born in, but perhaps not raised in. A whole generation of Romanian children is growing up with two potential citizenships. For many of these children, parents have not requested the Romanian one (and/or another in the case of mixed couples); hence, the question arises as to how the children themselves will relate to these administrative frames.

\section{The Feeling of Belonging to a Host Country}

Studies show that these children develop a hybrid identity (Vathi 2015) by developing a feeling of belonging both to the target country and the country of origin (Bratu 2015), although the families can sense their children's battle with difference. We shall present below the situation of three mothers. Lilla, from a binational (Romanian-Slovak) couple, lives in a temporary transnational situation and has three children in a third country. Raluca, from a couple comprising Romanian citizens, has returned "definitively" with her child from Canada. Krisztina, from another couple comprising Romanian citizens, has been raising her children in a temporary transnational situation in another country.

Lilla's children, who live in a family where the mother is a Romanian citizen and the father is Slovak, while possibly becoming Belgian, are confronting the burden of choice and have come to a clear decision as to their country: 
'My mother is from Romania, my father is from Slovakia', if someone asks them. And they are from Belgium. 'But we speak both Slovak and Romanian.', is what they say. (Lilla, Belgium)

Sergiu, who has dual Canadian-Romanian citizenship himself, while having fondly returned to Romania when he was five, at seven he increasingly wants to return to Canada:

Well, he has understood. At the start, I told him and he said, 'Yes, I want to go to Romania!' He was delighted! We went to the doctor and, at the last medical exam, he told him [in English], 'We are not coming back!', since he asked when he would be coming to the next exam. Yes, he was very delighted. On the other hand, we came here and first he didn't say anything... Frankly, I don't know. He said this, 'I miss Canada!', but he keeps saying this since we came... 'I want to go to Canada!' I told him we were going to visit, but I didn't have the time since there were events all the time, like that, whatever! And he says, 'I want to go to Canada! I miss Canada!' 'But, what exactly do you miss? Tell me what you miss.' What is his constant answer? 'Because I was born there!' (Raluca, Romania)

We encounter this choice of one country, regardless of citizenship, in the case of Gabriel as well, who lives in Belgium but was not born there, unlike his sister, who will have the right to claim Belgian citizenship by birth. However, he has nevertheless assumed Belgium to be his own country. Whenever he travels to Romania, he is happy, but wants to come back the next day:

'I want to go to my Belgium, I can hardly wait to get to my Belgium!' I don't know why he wanted to go so much to his Belgium, since they like it a lot in Romania. (Krisztina, Belgium)

The three mothers have expressed their worries concerning these attachments, especially since Raluca's family does not want to return to Canada, while Krisztina's wants to return to Romania and Lilla's also wants to settle in Romania in the future. But all three mothers have confessed that these wishes of children are not completely ignored, and that the parents take into consideration living in the country chosen by the children as well, provided that this option does not limit their financial and social opportunities too much. 


\section{Conclusions}

For these children born abroad or only raised there, the relationship with the home country seems to ameliorate a little, at least administratively. Registering children born outside the country, as well as their visits home- especially for those living in countries needing visas for Romaniabecomes more viable thanks to the new 2017 legislation, which has lifted all fees:

Do you know why I think we will succeed this time? Because before, when I went to make a document at the embassy, it cost between 80 and 100 dollars. [...] So, I was obliged to bring the money in dollars. But the law has changed and, since 3 February 2017, I reckon, all the documents, all the consular services are absolutely free! I also have children, you know... thus, having Romanian-Egyptian children, I was asked to pay [...] almost 100 dollars for the visa to go with my children to the country! [...] That is also why we visited very rarely, since I baven't been to Romania for seven years. But now everything has changed, now it is for free. (Cristina, Egypt)

That said, many other issues have to be managed by the parents who raise their children transnationally. Many studies have taken into consideration the role of children in parents' decisions to leave the country, but these have rather focused on the financial aspect of this decision. The case of Romanian children who are sent to study abroad, unaccompanied by close family members, is underresearched. The access of children to a given educational system seems to be an important argument when changing countries, rather than simply a pretext (Vlase 2013). Keeping the Romanian language is necessary for the children who move abroad with their parents-especially since most departures are temporary. But, in the case of children born abroad, especially those born to binational or nationally mixed couples, the situation gets more complicated, in respect of language, religion and citizenship. Alongside these challenges of transnational parenting is the fact that the sense of belonging (Vathi 2015; Bratu 2015) of children to a specific country is not always consistent with the future plans of their parents.

Concerning these situations involving children, which need to be tackled by Romanian transnational families, the voices of women have become relatively louder, in conformity with traditional Romanian 
society, where child raising and education are the responsibility of mothers (Santero and Naldini 2017). If we analyze the situation of children returning to the country in order to study, we observe that, with a single exception (the mixed couple of Shannon and Levi, where the mother is American, hence could not have managed by herself), mothers are rather the ones to be sent home to take care of the children. Romanian fathers, especially those from binational couples, involve themselves when the issue of children's citizenship arises, as well as that of their baptism in the Orthodox rite and learning the Romanian language, that is, the development of the Romanian side of their hybrid identity (Vathi 2015; Rysst 2016).

Funder: Executive Unit for Financing Higher Education, Research, Development and Innovation (UEFISCDI), project code: PNII-RU-TE2014-4-2087.

\section{REFERENCES}

Bezzi, C. (2013). Romanian "Left Behind" Children? Experiences of Transnational Childhood and Families in Europe. Martor, 18, 57-74.

Botezat, A., \& Pfeiffer, F. (2014) The Impact of Parents Migration on the WellBeing of Children Left Behind: Initial Evidence from Romania (Discussion Paper No. 8225). Bonn: IZA. http://ftp.iza.org/dp8225.pdf. Last View: $1 / 10 / 2017$.

Bradatan, C. E. (2014). The Interplay Between Family and Emigration from Romania. Migration Letters, 11(3), 368-376.

Bratu, R. (2015). Children of Romanian Migrants Between "Here" and "There": Stories of Home Attachment. Social Change Review, 13(1), 3-27. https://doi. org/10.1515/scr-2015-0007.

Carling, J., Menjivar, C., \& Schmalzbauer, L. (2012). Central Themes in the Study of Transnational Parenthood. Journal of Ethnic and Migration Studies, 38(2), 191-217. https://doi.org/10.1080/1369183X.2012.646417.

Coe, C. (2012). Growing Up and Going Abroad: How Ghanaian Children Imagine Transnational Migration. Journal of Ethnic and Migration Studies, 38(6), 913-931. https://doi.org/10.1080/1369183X.2012.677173.

Dermott, E., \& Seymour, J. (2011). Developing 'Displaying Families': A Possibility for the Future of the Sociology of Personal Life. In J. Seymour \& E. Dermott (Eds.), Displaying Families: A New Concept for the Sociology of Family Life. London: Palgrave Macmillan. 
Ducu, V. (2013). Romanian Migrant Women's Response to Their Discrimination. In T. Geisen, T. Studer, \& E. Yildiz (Eds.), Migration, Familie und soziale Lage: Beiträge zu Bildung, Gender und Care (pp. 195-123). Cham: Springer.

Ducu, V. (2014). Transnational Mothers from Romania. Romanian Journal of Population Studies, VIII(1), 117-141.

Ducu, V., \& Hossu, E. I. (2016). Bi-national Couples with a Romanian Partner in the European Context. In V. Ducu \& Á. Telegdi-Csetri (Eds.), Managing Difference in Eastern-European Transnational Families (pp. 131-151). Frankfurt am Main: Peter Lang.

Finch, J. (2007). Displaying Families. Sociology, 41(1), 65-81.

Finch, J. (2011). Exploring the Concept of Display in Family Relationships. In J. Seymour \& E. Dermott (Eds.), Displaying Families: A New Concept for the Sociology of Family Life (pp. 197-206). London: Palgrave Macmillan.

Gardner, K. (2012). Transnational Migration and the Study of Children: An Introduction. Journal of Ethnic and Migration Studies, 38(6), 889-912. https://doi.org/10.1080/1369183X.2012.677170.

Mazzucato, V., \& Schans, D. (2011). Transnational Families and the Well-Being of Children: Conceptual and Methodological Challenges. Journal of Marriage and Family, 73, 704-712. https://doi.org/10.1111/j.1741-3737.2011.00840.x.

Morgan, D. (2011a). Rethinking Family Practices. London: Palgrave Macmillan.

Morgan, D. (2011b). Locating 'Family Practices'. Sociological Research Online, 16(4), 14. http://www.socresonline.org.uk/16/4/14.html\&gt.

Moskal, M., \& Tyrrell, N. (2016). Family Migration Decision-Making, Step Migration and Separation: Children's Experiences in European Migrant Worker Families. Children's Geographies, 14(4), 453-467. https://doi.org/10.1080/ 14733285.2015.1116683.

Nagasaka, I., \& Fresnoza-Flot, A. (Eds.). (2015). Mobile Childhoods in Filipino Transnational Families, Migrant Children with Similar Roots in Different Routes. London: Palgrave Macmillan.

Popa, N. L. (2016). Grasping Parental Behaviours Through the Eyes of Romanian Adolescents Affected by Parental or Family Migration. Rivista Italiana di Educazione Familiare, 2, 71-80.

Rentea, G. L., \& Rotărescu, L. E. (2016). Yesterday’s Children, Today’s Youth: The Experiences of Children Left behind by Romanian Migrant Parents. In V. Ducu \& Á. Telegdi-Csetri (Eds.), Managing Difference in Eastern-European Transnational Families (pp. 151-170). Frankfurt am Main: Peter Lang.

Robila, M. (2011). Parental Migration and Children's Outcomes in Romania. Journal of Child and Family Studies, 20, 326-333. https://doi.org/10.1007/ s10826-010-9396-1.

Rysst, M. (2016). "I Think of Myself as Norwegian, Although I Feel that I Am from Another Country". Children Constructing Ethnic Identity in Diverse 
Cultural Contexts in Oslo, Norway. In M. L. Seeberg \& E. M. Gozdziak (Eds.), Contested Childhoods: Growing Up in Migrancy, Migration, Governance, Identities. Cham: Springer.

Sănduleasa, B., \& Matei, A. (2015). Effects of Parental Migration on Families and Children in Post-Communist Romani. Revue des Sciences Politiques, 46, 196-207.

Santero, A., \& Naldini, M. (2017). Migrant Parents in Italy: Gendered Narratives on Work/Family Balance. Journal of Family Studies. https://doi.org/10.1080 /13229400.2017.1345319.

Seeberg, M. L., \& Gozdziak, E. M. (Eds.). (2016). Contested Childhoods: Growing Up in Migrancy, Migration, Governance, Identities. Cham: Springer.

Sime, D., \& Fox, R. (2014). Home Abroad: Eastern European Children's Family and Peer Relationships. Childhood, 1-17. https://doi.org/10.1177/ 0907568214543199.

Spyrou, S., \& Christou, M. (Eds.). (2014). Children and Borders. London: Palgrave Macmillan.

Trias, P. H., Fres, N. F., Pasamontes, E. G., Martin Pujol, A., \& Berñe, A. L. (2013). Children and Teens on Transnational Migration: The Experience of Children Migrating from Romania to Spain with Their Families. In G. G. Valtolina (Ed.), Migrant Children in Europe: The Romanian Case (pp. 84-122). Amsterdam: IOS Press. https://doi.org/10.3233/978-1-61499-205-9-84.

Valtolina, G. G. (Ed.). (2013). Migrant Children in Europe: The Romanian Case. Amsterdam: IOS Press.

Valtolina, G. G., Colombo, C., Colombo, M., Fenaroli, V., \& Papavero, G. (2013). The Challenge of Identity: The Experience of Children Migrating from Romania to Italy with Their Families. In G. G. Valtolina (Ed.), Migrant Children in Europe: The Romanian Case (pp. 46-83). Amsterdam: IOS Press. https://doi.org/10.3233/978-1-61499-205-9-46.

Vathi, Z. (2015). Migrating and Settling in a Mobile World, Albanian Migrants and Their Children in Europe. Cham: Springer.

Vlase, I. (2013). 'My Husband Is a Patriot!': Gender and Romanian Family Return Migration from Italy. Journal of Ethnic and Migration Studies, 39(5), 741-758. https://doi.org/10.1080/1369183X.2013.756661.

Wentzell Winther, I. (2015). To Practice Mobility - On a Small Scale. Culture Unbound, 7, 215-231.

White, A., Ní Laoire, C., Tyrrell, N., \& Carpena-Méndez, F. (2011). Children's Roles in Transnational Migration. Journal of Ethnic and Migration Studies, 37(8), 1159-1170. https://doi.org/10.1080/1369183X.2011.590635. 
Open Access This chapter is licensed under the terms of the Creative Commons Attribution 4.0 International License (http://creativecommons.org/licenses/ by $/ 4.0 /$ ), which permits use, sharing, adaptation, distribution and reproduction in any medium or format, as long as you give appropriate credit to the original author(s) and the source, provide a link to the Creative Commons license and indicate if changes were made.

The images or other third party material in this chapter are included in the chapter's Creative Commons license, unless indicated otherwise in a credit line to the material. If material is not included in the chapter's Creative Commons license and your intended use is not permitted by statutory regulation or exceeds the permitted use, you will need to obtain permission directly from the copyright holder. 